\title{
THE PROPOSED PENNSYLVANIA MINIMUM WAGE ACT
}

\author{
By William Draper Lewis, \\ Dean, Law School, University of Pennsylvania.
}

The Pennsylvania Republican state convention which met in Harrisburg last May was controlled by the Progressive forces. It pledged the party to the enactment of a fair act regulating the employment of women and children, and appointed a legislative and executive committee to draft the legislation.

When the committee met it at once determined to draft a bill regulating the hours of employment of children and the sanitary and other physical conditions of their employment; and another bill regulating the hours of employment of women and the sanitary conditions in manufacturing and other establishments. These bills have been drafted. They are the child labor bill, and the women's labor bill, now pending before the legislature. I believe that it can be said of each measure that it is a model act of its kind. Of necessity, however, these bills relate primarily to employment in establishments. It is not practicable to regulate the number of hours which a woman or child may labor on work taken home. The bills referred to, therefore, do not pretend to correct the evils of the so-called sweatshop. Indeed, by the fact that they require manufacturers to improve the sanitary conditions of their mills and factories, and also prevent the exploitation of the woman and child worker by long hours of employment, to some extent they create conditions which give an advantage to the employer who puts out his work to be done at the homes of his employees.

Under-payment is the main source of all the evils of the sweatshop system. Sweat-shop labor is always paid for by the piece. Under-payment makes necessary long hours of labor. Under-payment also makes it impossible for the laborer to procure a sanitary place in which to work. Thus it is that the more enlightened the legislation dealing with the hours of labor and the sanitary conditions of employment in manufacturing and other establishments, the more 
necessary it is to prevent under-payment whether the employee works in a mill or in her own home. The legislative and executive committee therefore, after having drafted a child labor bill and a bill regulating the hours of employment of women, came to the conclusion that a minimum wage act was not only advisable in itself, but was an essential part of any program of legislation designed to carry out a platform which had specifically pledged the enactment of "a fair law regulating the employment of women and children."

I shall refer briefly to the main features of the minimum wage bill prepared by the committee and now pending before the house of representatives. It has been favorably reported by the committee to which it was referred. ${ }^{1}$

The first section sets forth the principle on which the bill is founded. It recites "that it is the belief of the general assembly that the public health and welfare demand that every female over sixteen years of age employed by or permitted to work for any person within this commonwealth be compensated at such a rate as will enable her to support and maintain herself in health and reasonable comfort, and that every child under sixteen years of age employed by or permitted to work for any person within this commonwealth receive compensation at a rate at which it can earn an amount necessary to enable its parent or guardian to support and maintain it in health and reasonable comfort."

The three main factors affecting employment are the sanitary and other physical conditions under which the work is performed, the hours of labor, and the rate of wages. Under-payment is just as surely a cause of physical deterioration and disease as over-work or unsanitary conditions.

Our courts have determined that an act which regulates in a reasonable manner sanitary conditions, or an act which places a reasonable maximum on the hours of employment is constitutional, even though such acts do limit the theoretic freedom of contract between employer and employee. The constitutionality of a minimum wage act rests on exactly the same reason which today supports reasonable regulations of the hours of labor and the physical conditions under which the labor may be performed.

${ }^{1}$ It is now, May $3 \mathrm{~d}$, pending before the senate, having passed the house by a large majority. 
In order to prevent under-payment the act provides for a commission of three persons to be known as the Wage Commission of the Commonwealth of Pennsylvania. The commission has power to investigate what should be the lowest wage rate in any industry. The problem here is similar to the problem confronting the draftsmen of an act to regulate public service corporations. The obligation of a public service corporation is to give the public efficient service at reasonable rates. In the same way the minimum wage act imposes on an employer of women and children the obligation to pay the former a rate of wages on which they can maintain themselves in health and reasonable comfort, and the latter a rate which will equal the cost of their maintenance by parent or guardian. It has been determined, however, that it is necessary for the legislature in creating a public service commission to give to the commission a standard by which the commission can fix the reasonable rate. This is necessary to overcome the constitutional objection that the commission in fixing the rate exercises a legislative rather than an administrative function. In our constitutional system there can be no delegation by the legislature of legislative functions. So in the minimum wage bill it is necessary to give the commission a rule by which they may determine a reasonable minimum rate. This is done in the 13th section of the proposed bill which provides that, "The commission shall have power upon investigation to determine the lowest rate in any industry or branch thereof, commuted either by time or piece or in any other manner, at which a female over sixteen years of age of average ability and skill can earn, in a number of hours a female over sixteen years of age may lawfully work in any establishment in any one week, compensation sufficient to support and maintain herself in health and reasonable comfort for seven days." Under the women's hours of work bill. prepared by the same committee, a woman may lawfully work as much as fifty hours in any one week or nine hours in any one day.

Section 15 provides that after having determined a rate of compensation the commission shall issue an order prohibiting the payment to such females at less than the prescribed rate. Similar provision is made for ascertaining the rate at which children under sixteen years should be paid and for issuing an order requiring the payment of the rate fixed by the commission. 
Special provision is made in the bill for females who are physically defective. Where a time rate only has been fixed for an industry the commission may issue a special license authorizing such defective female to be paid at a rate fixed by the commission which rate may be lower than the lawful rate for other females. The commission may also include in any order fixing a rate of compensation for any industry, appropriate provisions exempting apprentices from the operation of the order, and regulating the payment of such apprentices. In order to prevent the exception in relation to apprentices being used as a means to evade the act, the commission is given power to limit the number of persons who may be paid as apprentices under the general order of the commission, and also to fix the maximum period of time during which a worker in any industry may receive compensation as an apprentice.

The procedure before the commission and the method of enforcing the orders of the commission have been modeled on the provisions of the best public service commission acts in the country. Thus, whenever the commission is of the opinion that its orders are being violated it may institute in the court of common pleas of the proper county proceedings to obtain an injunction to restrain such violation. The attorney-general is directed on the request of the commission to institute such proceedings. 